\title{
Onbeantwoorde vrae in die wetenskap: Laat ons die studente en jong navorsers daarmee uitdaag
}

P Smit
Universiteit van Pretoria

\begin{abstract}
The university - an institution of hope.

The university is a institution of hope where the foundations are laid for $a$ better future. This derives from the search for. solutions in every sphere of scientific study. Sometimes students and young researchers are concerned that the most interesting scientific questions have already been answered. But clearly even a fraction of the unanswered questions in science pose incredible challenges to researchers and students in every field of scientific endeavour. Apart from the global challenges presented by science, South Africa must be one of the most interesting laboratories on earth. The critical ability to put the right questions to science through dedication and hard work is indeed the key to all research and education.
\end{abstract}

Hierdie funksie waartydens die Universiteit van Pretoria erkenning aan sy uitnemende presteerders gee, is, naas die amptelike opening van die akademiese jaar en die verwelkoming van eerstejaarstudente, een van die belangrikste funksies op die kampus. Daar is ook die mooi gebruik om die toppresteerders, dit is dié wat meer as vyf onderskeidings in matriek behaal het, as nuweling-eerstejaars te velkom. Dié funksie staan as die voorvlieërfunksie bekend, omdat ek altyd die beeld van voorvlieër-posduiwe op. hierdie toppresteerders van toepassing maak.

'n Voormalige rektor van die Katolieke Universiteit van Leuven het tereg opgemerk '... het welzijn van een volk hangt nu eenmaal af van zijn meer begaafden en het welzijn van de minder begaafden hangt af van die inspanning van de meer begaafden'. $U$ is die begaafdes van ons Universiteit en ons land. Op u rus daar 'n groot verantwoordelikheid. $U$ het ook 'n wonderlike geleentheid om oplossings vir die onbeantwoorde vrae in die wetenskap te probeer vind en daardeur ' $n$ bydrae tot nuwe kennis in die wetenskap te lewer. Deur dit te doen, sal u die welsyn van ons land en al sy mense bevorder.

\footnotetext{
* Rede gelewer deur die Visekanselier en Rektor van die Universiteit van Pretoria, by geleentheid van die funksie vir uitnemende presteerders op 6 Mei 1996.
} 
'n Universiteit is 'n plek van hoop waar die grondslae vir 'n beter toekoms gelê word. Indien oplossings vir die land se vraagstukke op nywerheidsgebied en op sosioekonomiese gebied nie by die universiteite gevind word nie, kan tereg gevra word waar elders dit gevind sal word.

Afgesien van die globale uitdagings wat die wetenskap bied, is Suid-Afrika seker een van die interessantste laboratoria in die wêreld om in te werk. 'n Mosaïek van volke, tale, kultuurvlakke, 'n ongekende verskeidenheid van geologiese en grondsamestellings wat saam met wisselende klimaatverskille die grootste verskeidenheid van plante en diere binne die grense van een land groepeer. Ons myne raak al dieper en ertse al moeiliker om te ontgin. Indien ons nie oplossings vind nie, sal ons nie kompeterend bly nie.

In ons stede en dorpe bestaan daar skrille kontraste van, byvoorbeeld, rykdom en armoede, werkloosheid by ongeletterdes en skaarsheid aan geskoolde mensekrag. Aan die een kant daag die wetenskap ons uit om saam met internasionale wetenskaplikes oplossings te probeer vind vir klimaatsveranderinge en die toepassing en besturur van hoë tegnologie, maar aan die ander kant moet ons oplossings vind om ongeletterdheid te oorkom, die algemene gesondheidspeil van ons bevolking deur primêre gesondheidsorg te verbeter en demokrasie na almal uit te brei, sonder om die prosesse van bestuur daardeur tot stilstand te dwing.

Somtyds is studente en jong navorsers bekommerd dat die interessantste vrae reeds aangespreek is, dat daar nie meer interessante temas vir verhandelinge, proefskrifte en navorsingsprojekte is nie. Die mikrovlokkie is mos uitgevind en kan nog net verbeter word en gene is mos reeds gekloon. Volgens professor Van den Beukel, hoogleraar in Natuurkunde aan die Technische Universiteit Delft, glo sommige vooraanstaande fisici dat alles in die natuurkunde vanaf die oerknal tot en met die toekoms weldra in kompakte formules uitgespel en verstaan sal wees.

Ek wil volle erkenning gee aan professor Charles M Vest, President van MIT, wat in sy Report of the President for the Academic year, 1994-1995 'n aantal van sy kollegas gevra het om die onbeantwoorde wetenskaplike vrae in hulle dissiplines aan te stip. Insgelyks my dank en waardering aan die kollegas, waarvan baie vanaand as uitnemende presteerders hier teenwoordig is, wat so gunstig op my versoek gereageer het om die onbeantwoorde vrae in hulle dissiplines in internasionale en nasionale verband uit te wys. Dit was fassinerend om die antwoorde te bestudeer. Ek haal vrylik uit die werk van professor Vest en dié kollegas aan. In die kort voordrag kan ek slegs 'n breukdeel van hierdie onbeantwoorde vrae in die wetenskap aan u oordra. Ek hoop dat dit $u$ sal stimuleer en dat dit ons veral onder die besef sal bring hoe min ons werklik weet en watter uitdagings die wetenskap werklik aan ons bied. 
Ek glo u sal saamstem dat klimaatsveranderinge 'n enorme invloed op die mens en sy voortbestaan het. Die invloed van die mens, veral die verbranding van fossielbrandstof, mag dramatiese klimaatsveranderinge teweegbring. Wetenskaplikes stem oor die algemeen saam dat daar ' $n$ noodsaak is om klimaatsveranderinge te voorspel en volgens hulle is dit een van die '... greatest challenges we face in the natural sciences'. Nogtans weet ons nie '... even in principle, which aspects of climate are predictable'. Insgelyks weet ons ook nie watter tipe aardbewegings voorspel kan word nie. Die mees verfynde instrumente het nie voöraf seine gegee van aardbewings by Kobe in Japan of Northridge in Kalifornië nie en mense kon dus nie teen die naderende rampe gewaarsku word nie.

Indien die gedrag van fisiese sisteme moeilik is om te verstaan, is die gedragspatrone van mense nog moeiliker.

Daar is baie gesofistikeerde data oor ekonomiese groei. Tog weet ons nie presies waarom verskillende lande beide of op 'n bepaalde tydstip of oor tyd verskillend groei nie. Regerings verloor steeds verkiesings omdat hulle nie ekonomiese groei kan stimuleer en handhaaf nie. Dit kan wêreldwye onstabiliteit veroorsaak. In die SuidAfrikaanse kontəks het min, indien enige ekonome, die skerp daling in die waarde van die rand voorspel. Ekonome stem klaarblyklik ook nie saam oor watter faktor die grootste bydrae tot die daling gelewer het nie. In die Suid-Afrikaanse verband het ons geen oplossing vir die vraagstuk van werkloosheid nie. Selfs met 'n opswaai in die ekonomie het daar steeds ' $n$ daling in die aantal werkers in die nywerheidsektor plaasgevind.

In my eie dissipline, die demografie, weet ons nog nie presies watter uitwerking opvoeding, beter behuising en 'n beter lewenstandaard op geboortekoerse het nie. Ons kan ook nie die hoë fertiliteitsgordel wat vanaf Oos-Afrika deur Zimbabwe tot aan die Ooskus van Suid-Afrika strek, verklaar nie. Ons kan ook nog nie die verskille in fertiliteit tussen die verskillende swart etniese groepe verklaar nie. Indien ons egter nie geboortekoerse laat daal nie, sal ons Heropbou- en Ontwikkelingsprogramme geen bydrae tot die verhoging van die algemene lewenstandaard te lewer nie.

Daar bestaan groot onduidelikheid oor hoe die suksesvolle organisasie van die toekoms sal lyk. Watter maatskappye sal floreer en watter sal tot niet gaan? Baie van die topmaatskappye van die wêreld wat 'n paar jaar gelede floreer het, staar bañkrotskap of oorname in die gesig.

Die inligtingrevolusie veroorsaak steeds verreikende veranderinge in organisasies. Selfs die bestaan van die nasiestaat is in gevaar. Internet het die potensiaal '... to create a new kind of society, an entity in itself. Netwerke sal die wese van gemeenskappe en van ons daaglikse lewe beinvloed. Hoe gaan die grootskaalse geïntegreerde netwerksisteme beheer en bestuur word? 
In die Suid-Afrikaanse verband moet ons vra watter rol inligting in die proses van ontwikkeling speel? Hoe verloop die proses van ontwikkeling en hoe kan inligting die proses aanhelp?

Op die kontakvlak van leerontwikkeling en inligtingtegnologie weet ons nie werklik hoe om die inligtinginfrastruktuur en die nuwe media te gebruik om die leerproses by kinders te bevorder nie. Dit geld veral omgewinggestremde kinders. Ons weet ook nie hoe om lewenslange leer by volwassenes te bevorder nie.

Om toegang tot inligting te hê is een saak, maar om dit nuttig te gebruik en te verstaan is ' $n$ perd van ' $n$ ander kleur. 'There is no greater mystery than how we learn, remember, think and communicate, and there is no field in which major advances would have more profound effects for human progress and health'. Ons weet nie wat die chemiese of fisiese aard van inligtingberging in die brein is nie. Daar is rede om te glo dat op hierdie terrein groot deurbrake nog gemaak sal word.

Insgelyks verstaan ons nie die verbind tussen taal en denke nie. Sonder basiese taalvaardighede is rekenaargeletterdheid buite die kwessie. Dit is moontlik dat tot $40 \%$ van die inwoners van Suid-Afrika nie basies geletterd is nie. Ons weet nie waarom en hoe sommige kinders klaarblyklik leer om te lees met dieselfde gemak as wat ander 'n taal bemeester nie. Indien ons kan uitvind, sal ons waarskynlik in staat wees om ons leesonderrig baie te verbeter en ongeletterdheid te verminder.

Ons weet nie hoe om materiale te produseer wat nie afvalstowwe ten gevolg het en besoedeling veroorsaak nie. Die onttrekking van energie uit fossielbrandstof is nie baie effektief nie. Op die gebied van sonenergie moet daar nog baie werk gedoen word ten einde sonenergie om te skakel tot koste-effektiewe brandstowwe vir 'n verskeidenheid gebruike.

Katalisators vorm die boustene van die meeste prosesse in die chemiese, petroleum en farmaseutiese bedrywe. 'And yet we do not know how to design catalysts for many important chemical reactions'. Ons weet reeds hoe supergeleiers teen lae temperature werk, maar ons verstaan nog nie heeltemal die werking van hoë-temperatuur supergeleiding nie.

Die biologiese wetenskappe bied van die mees gekompliseerde uitdagings. Groot pogings word aangewend om 'n basis vir biologie te probeer vind. Hierdie pogings word in 'n baie groot mate toegespits op begripsvorming rondom proteien wat onder meer 'n grondslag behoort te vorm vir die verstaan van DNA. Vir hierdie doel word interdissiplinêre navorsing gedoen waarby die heel fundamentele wetenskaplike dissiplines, Wiskunde, Fisika en Chemie, betrokke is. Hierdie navorsing is bestem om 'n fundamentele raamwerkverskuiwing in veral die Fisika, te bewerkstellig. In die wiskunde het daardie verskuiwing reeds die afgelope aantal jare plaasgevind met die opbloei van kombinatoriese wiskunde. 
Die veronderstelling dat DNA die sleutel tot fundamentele biologie is, kon na veertig jaar nog nie bevestig word nie. Dit is nie eens duidelik hoe die ou wette van Mendel oor oorerflikheid uit DNA-oorwegings afgelei kan word nie. Op die grondslag van DNA alleen kan daar nie groot verskille tussen families uitgewys word nie, om nie eens van verskille tussen genera te praat nie. Wat egter die meeste pla, is dat die gedrag van byvoorbeeld diere, en die wisselwerking tussen spesies en die omgewing waarskynlik glad nie binne hierdie raamwerk verklaar kan word nie. Die vermoede bestaan dus dat benewens DNA, daar ook ander fundamentele konsepte is wat nog ontdek moet word.

Daar is nog baie onbeantwoorde vrae op die gebied van siektetoestande soos vigs, kanker, malkoeisiekte, tuberkulose, malaria ensovoorts. Daar sterf elke dag sowat 50000 mense in die wêreld aan siektes wat deur water en voedsel versprei word. Die impak van hierdie siektes word sprekend geillustreer deur dit gelyk te stel aan stralers met elk 400 kinders en 100 volwassenes aan boord wat ononderbroke elke 30 minute neerstort sonder dat enige passasiers dit oorleef.

Op landbougebied is daar baie onopgeloste vraagstukke. Na meer as 100 jaar se navorsing op internasionale vlak is die oorsaak van die vernietigende siekte sitrusskroei (citrus blight) nog nie vasgestel nie en kan dit nog nie beheer word nie. Die implementering van die biologiese beheer van plantsiektes is nog grootliks oneffektief en genetiese manipulasie staan volgens sommige wetenskaplikes nog in sy kinderskoene.

Daar bestaan eeu-oue vrae oor die heelal. 'We do not know how old the universe is, what it is made of, or what its fate will be. We do not know if stars other than our own sun have earthlike planets capable of restoring life ....' Hierdie vrae oor die heelal maak dat ons Psalm 8 opnuut lees: 'As ek u hemel aanskou, die werk van u vingers, wat is die mens ...'.

Dit bring ons nader aan die godsdiens. Die beroemde historikus Paul Johnson het onlangs 'n boek getiteld The Quest for God gepubliseer: Baie wetenskaplikes het God dood verklaar of sy bestaan as 'n legende beskryf. In die verband kan daar verwys word na die sogenaamde Jesus Seminar wat probeer kwantifiseer wat waar en onwaar in die Bybel is. Johnson vra waarom geloof in God tot in die twintigste eeu bly voortbestaan liet en of daar selfs tekens van geloofsoplewing is? Johnson antwoord self die vrae deur te verklaar dat geloof in God bly voortbestaan eenvoudig omdat God bestaan.

Een van. die belangrikste fasette van die teologie as wetenskap is die lees van antieke tekste. Hoewel die teologie een van die oudste wetenskappe is, is daar nou nog nie duidelikheid oor hoe 'n antieke teks gelees moet word nie. Een van die belangrikste uitdagings op die internasionale terrein is juis om leesstrategieë vir antieke tekste steeds te verfyn en om die rol van die leser nader te omskryf. 
In aansluiting hierby is een van die grootste uitdagings vir die teologie om die antieke tekste te interpreteer en vir die Suid-Afrikaanse situasie relevant te maak. Die hermeneutiek - dit is die wetenskap wat hom besig hou met die interpretasie en aktualisering van tekste - sal hierin 'n baie belangrike rol moet speel om te voorkom dat die teologie ' $n$ ivoortoringwetenskap word.

Die pluraliteit van godsdienste, volke en kulture in Suid-Afrika vereis dat in 'n 'demokratiese samelewing daar oor sake op gelyke vlak onderhandel moet word. Tradisioneel het die aanhangers van die Christelike godsdiens hulle aansprake geproklameer, omdat hulle daarvan oortuig was dat hulle die Waarheid verkondig. Die vraag is nou: Hoe kan hulle binne 'n demokratiese bestel, waarin plurale beskouings voorkom, aan die Waarheid vashou sonder om hulself daarmee na die grens van die samelewing uit te skuif?

Dit verg toewyding en harde werk om die regte vrae in die wetenskap te vra. 'Being able to shape good questions is a critical capacity for every teacher and learner; it is the key to education'.

Ek wens al ons uitnemende presteerders van harte geluk met hulle prestasies. Ons is trots op u. Mag die Universiteit in die jare wat kom in staat wees om ' $n$ navorsingsklimaat te skep sodat dosente deur navorsing die vermoë behou om die regte wetenskaplike vrae te vra. Ek het geen twyfel dat hierdie begaafde studente wat voor my sit met entoesiasme sal reageer en met gemotiveerdheid sal werk om antwocide op die vrae te lewer nie. Namens die Universiteit wens ek u voorspoed met u studies toe. 